Research Article

\title{
Examining the Abrasion Behaviour of PA 66 Gears in Different Cycles
}

\author{
Rifat Yakut $^{1}$ and Hayrettin Düzcükoglu ${ }^{2}$ \\ ${ }^{1}$ Hema Endüstri A.S Organized Industrial Zone, Çerkezköy, Tekirdag, Turkey \\ ${ }^{2}$ Mechanical Education Department, University of Selçuk, Campus, Konya, Turkey \\ Correspondence should be addressed to Rifat Yakut; rifatyakut@hattat.com.tr
}

Received 5 December 2013; Revised 7 April 2014; Accepted 7 April 2014; Published 9 June 2014

Academic Editor: Yuanhua Lin

Copyright (C) 2014 R. Yakut and H. Düzcükoglu. This is an open access article distributed under the Creative Commons Attribution License, which permits unrestricted use, distribution, and reproduction in any medium, provided the original work is properly cited.

Gears made of plastic-based materials are anticorrosive, resistant to magnetic environments, and light and have pulse decay, low noise, and self-lubrication properties, and therefore their usage areas are widening every single day. In this experiment, the working conditions of 30\% fibreglass PA 66 (PA 66 GFR 30) plastic material with PA 66 (PA 66 GFR 30) plastic material and AISI 8620 couple gear are observed. Usage of PA 66 GFR 30 material as gear material at $56.75 \mathrm{Nm}$ constant load and $750 \mathrm{rpm}, 1000 \mathrm{rpm}$, and $1500 \mathrm{rpm}$ was analysed. The load capacity damage formation of the material was also analysed. The tooth surface temperature, corrosion depth of the tooth profile, tooth damage, and the tooth surface were examined with an scanning electron microscopy (SEM) and the corrosive behaviour of gears was analysed.

\section{Introduction}

Gears provide engineering and cost advantages while transmitting mechanical power and they are used in a wide area from clock mechanisms to cars, benches, and space flight technology. Gears are important machine elements that provide motion or power transmission $[1,2]$. The most important expectation in gear systems is transmitting energy without a major loss and keeping efficiency at maximum. The most forcing factor during energy transmission is friction and the corrosion it causes. These negative effects occur on gears as well as on other machine parts thereby causing financial losses [3]. The reason why plastic gears are most preferred in industry is that they have lots of advantages compared to metal gears. These advantages are low noise, lightness, and self-lubrication. Low load capacity, short lifetime, and low heat resistance are the disadvantages of plastic gears [4]. When plastic and metal surfaces are operated together, the smoothness of the surfaces is one of the most important factors that affects corrosion [5]. Plastic gears have properties such as silent and unlubricated operation, lightness, appropriateness for serial production, pulse decay, and production economics. Disadvantages are low load capacity, low thermal conductivity, and low consistency in determining the lifetime of the material. If the couple gear selected is AISI 8620 or a gear is made of cast iron, then the load capacity will be much higher $[6,7]$. Plastic materials have significantly low resistances when compared to AISI 8620 at nominal temperatures. They are lighter and they have higher pulse decay. They are nonconductors, have colour, and also have low heat resistance. Plastics do not corrode because they are nonconductors. They can absorb water. This means water can fill the spaces between macromolecules. This absorption property affects resistance values and other properties negatively. The properties of plastics can be enhanced by adding agents [8]. Plastic gears made of fibre-reinforced thermoplastics have higher performance than those made of nonreinforced polymers [9]. Plastic materials have smaller modules than metals. Therefore tooth rupture occurs more in plastic materials than in ANSI 8620 gears [10]. Mechanical properties of polymers are affected proportionally to the load ratio when compared with metals. Tooth temperature and resistance of the material effect the cycle of the gear and this determines the load frequency of the polymer gear [11]. Plastic gears have some advantages like silent operation and self-lubrication compared with steel gears, but, because 
TABLE 1: Geometric properties of the experimental gears.

\begin{tabular}{|c|c|c|}
\hline & Driven & Driving \\
\hline \multirow{2}{*}{ Tooth material } & PA 66 GFR 30 & PA 66 GFR 30 \\
\hline & PA 66 GFR 30 & AISI 8620 \\
\hline Module & \multicolumn{2}{|c|}{4,5} \\
\hline Tooth count & \multicolumn{2}{|c|}{20} \\
\hline Pressure angle $\left(^{\circ}\right)$ & \multicolumn{2}{|c|}{20} \\
\hline Arc of engagement $\left({ }^{\circ}\right)$ & \multicolumn{2}{|c|}{22,44} \\
\hline Profile Shifting (+x) & \multicolumn{2}{|c|}{0,177} \\
\hline Pitch diameter (mm) & \multicolumn{2}{|c|}{90} \\
\hline Major diameter (mm) & \multicolumn{2}{|c|}{100.593} \\
\hline Thread width (mm) & 14 & 18 \\
\hline Distance between axes ( $\mathrm{mm})$ & \multicolumn{2}{|c|}{91,5} \\
\hline Contact ratio & \multicolumn{2}{|c|}{1,496} \\
\hline
\end{tabular}

TABLE 2: Mechanical properties of the experimental gears.

\begin{tabular}{lcc}
\hline & PA 66 GFR 30 & AISI 8620 \\
\hline Density $\left(\mathrm{gr} / \mathrm{cm}^{3}\right)$ & 1.14 & 7.85 \\
Elastic module $\left(\mathrm{N} / \mathrm{mm}^{2}\right)$ & 70 & 560 \\
Thermal conductivity W/(K.m) & 0.28 & 46.6 \\
Hardness value & M80 & $56 \mathrm{HRC}$ \\
Elasticity drawing module & 3000 & 205000 \\
\hline
\end{tabular}

TABle 3: Experiment conditions.

\begin{tabular}{lc}
\hline Applied tooth load $(\mathrm{N} / \mathrm{mm})$ & 56.75 \\
Operating speed (rpm) & $750,1000,1500$ \\
Total cycle time & $7.2 \times 10^{5}$ (12 hours) \\
Ambient temperature & $18-23^{\circ} \mathrm{C}$ \\
Humidity & $45-60 \%$ \\
\hline
\end{tabular}

of their low load capacity and low thermal conductivity, thermal damages occur more often on the tooth surface. Because of this, it is very important to determine the working conditions of plastic gears to maximize their lifetime. This will enable the user to take precautions, predict damages, and change gears at need. In this experiment we observed thermal damage occurrence on gear surfaces in different conditions and studied their operating performances.

\section{Material and Method}

2.1. Material. The gear material PA 66 GFR 30, which was taken from the Kahvecioğlu Plastik company, was moulded into the injection container prepared at Gazi University with a cooling fluid and the desired tooth dimensions applied at a $\mathrm{CNH}$ counter. The dimensions and properties of the experimental gears are shown in Tables 1 and 2 .

2.2. Method. An FZG tester was used as the gear tester (Figure 1) $[12,13]$ and the experimental conditions are shown in Table 3. Sample gears were operated at low load $(3 \mathrm{~N} / \mathrm{mm})$ and low speed 350 (rpm) for 10 minutes. Every experimental condition was repeated six times and the average of

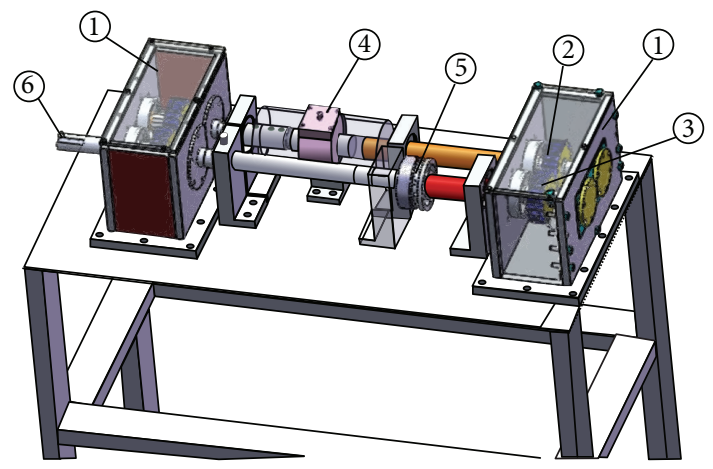

(1) Gear case

(2) PA 66 GFR 30 sample gear

(3) AISI 8620 sample couple gear

(4) Torque coupler

(5) Stress coupling

(6) Motor shaft

Figure 1: FZG test device $[12,13]$.

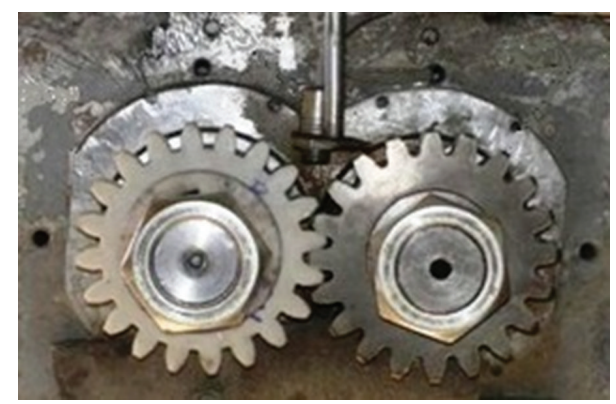

FIGURE 2: Measurement of tooth temperature [14].

the outcomes was calculated. An Infratherm pyrometer 510$\mathrm{N}$ thermometer was placed $5 \mathrm{~mm}$ away from the tooth contact point to measure the tooth surface temperature. By doing this, momentary measurements of the tooth temperature were indicated (Figure 2) [14]. The sample gears kept operating during the experiment except for the tooth rupture damage.

\section{Results and Discussion}

The lifetime of a tooth is expressed as the contact count of a gear tooth under load with the couple tooth in terms of hours [8]. With the increase of cycle at $56.75 \mathrm{~N} / \mathrm{mm}$ tooth load, the temperature of the pitch circle increased proportionally to the increase in abrasion. Thermal damages and ruptures were observed because of the thermal fatigue. The temperature changes that occurred on the tooth surface are shown in Figures 3 and 4 .

As shown in Figure 3, a PA 66 GFR 30 and PA 66 GFR gear couple operated in $1500 \mathrm{rpm}$, soon after the starting heat on the tooth profile increased rapidly. Because of this high heat accumulation, big particles flaked off the surface (Figure 5). After this tooth profile wear, the required moment could not be transmitted and decompression occurred. Test gears completed their lifetime damaged but without fracture. 


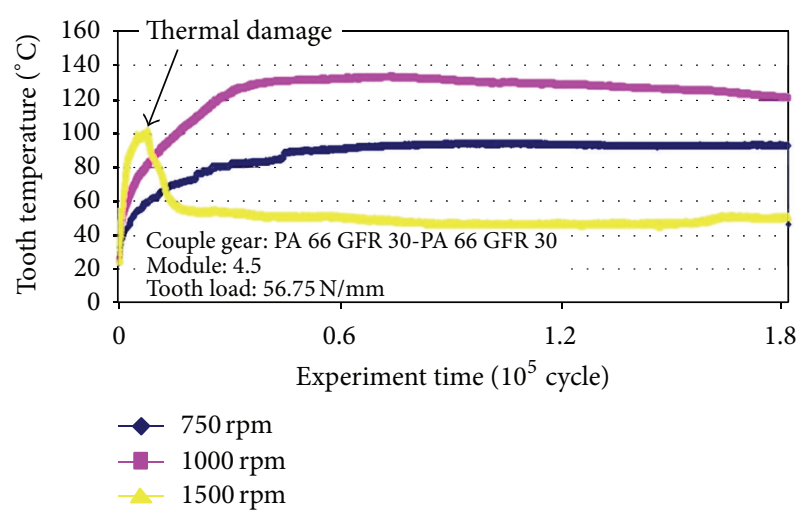

FIGURE 3: $56.75 \mathrm{~N} / \mathrm{mm}$ tooth load, different cycles, and module 4.5 PA 66 GFR 30-PA 66 GFR 30. Temperature changes of gear and tooth surface.

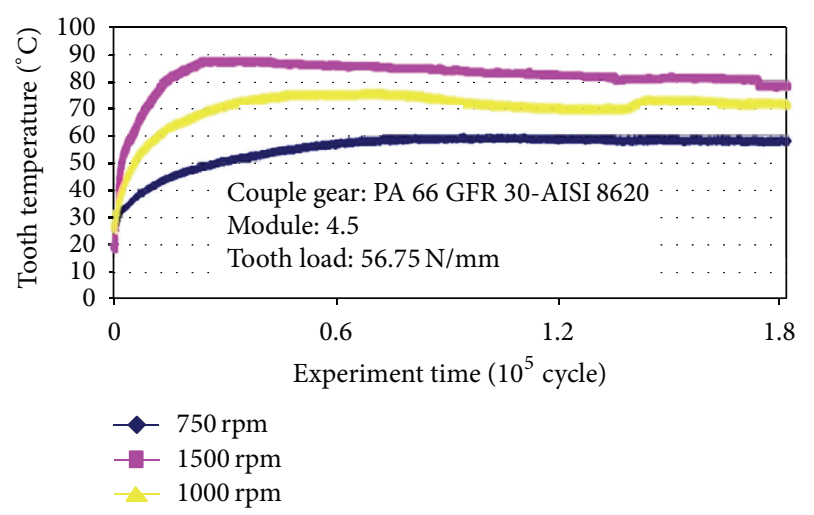

Figure 4: $56.75 \mathrm{~N} / \mathrm{mm}$ tooth load, different cycles, and module 4.5 PA 66 GFR 30-AISI 8620. Temperature changes of gear and tooth surface.

During low speed operation because of thermal conduction no thermal damage occurred but corrosion was observed over time. Test gears acquired thermal balance in the end.

Tooth temperature changes according to the amount of profile wear and the time after thermal balance has been reached. Sudden fractions occur when tooth temperature rises, when load changes, and when bending stress changes. Therefore we need heat protection for the gear to prevent overheating. Heat must be conducted properly. The temperature change of the gear profile should happen slowly.

In Figure 4 steel couple gear conducts the heat from the plastic gear to itself. The steel gear then discharges the heat to the environment and thermal balance is reached. No thermal damage occurred in any of the test gears in this experiment (see Figure 6).

Gears are operated in a dry environment on an FZG test device according to determined parameters. After this operation, the tooth wear of gears is examined under $20 \mathrm{x}$ magnification with a profilometer device. To this end, the original profile was drawn with the help of the GearTrax 12 program. Wearing rate is determined by comparing worn tooth profile of the gear with original tooth profile (Figures 7 and 8$)$.
To increase abrasion resistance and usage of PA 66 as gear material, fibreglass can be added to the material to provide higher tooth load and increased cycle. While operating PA 66 GFR 30-PA 66 GFR 30 couple gears, as seen in Figures 5 and 7, plastic materials cannot give the heat off. Because of this, material softens and this causes thermal and tooth damage. The temperature observed during operation also decreases the endurance of gears $[15,16]$. Continuous load increased the heat of the material and this led to fracture, melt, and rupture on the tooth surface. These results are shown in Figure 9(a) by SEM images. Because of the shear rate, particles ruptured on the tooth surface, leaving it pitted. Glass fibres in PA 66 GFR 30 material were ruptured after the corrosion effect on the contact surface.

While operating PA 66 GFR 30-AISI 8620, under constant $56.75 \mathrm{~N} / \mathrm{mm}$ load and increasing rotation, at first the tooth temperature increased and then the temperature became constant. AISI 8620 couple gear has great thermal conductivity. It absorbs the heat from PA 66 GFR 30 and spreads it to the body until thermal balance, as you can see in Figure 4. The depreciation of the tooth profile caused by thermal fatigue is shown in Figures 6 and 8. It is recommended that plastic gears in high-speed systems should be coupled with AISI 8620 gears [17]. The rotator and the couple have different dimensions. Therefore shear occurs on the tip and root surface of the tooth. Shear rate changes during the operating period and reaches zero at the contact point of the rolling circle. The direction of the friction force on turned gears is towards the contact points of gears. As shown in the SEM image in Figure 9(b), friction force causes corrosion on the tips and roots. Deformation of plastics occurs more because of the viscous flow than because of shearing. Viscous flow happens when polymer's chains come one on another. This causes the tooth surface to soften and leads to rupture.

\section{Results}

(a) When PA 66 GFR 30 gear material was coupled with PA 66 GFR 30, the gear produced more body temperature than AISI 8620 couple gear.

(b) With PA 66 GFR 30-PA 66 GFR 30 couple gears at $56.75 \mathrm{~N} / \mathrm{mm}$ tooth load and $1500 \mathrm{rpm}$, thermal damage and rupture occurred because of heat accumulation within the tooth, especially under the pitch circle. At $750 \mathrm{rpm}$ and $1000 \mathrm{rpm}$ heat accumulations were observed under the pitch circle.

(c) With PA 66 GFR 30-AISI 8620 couple gears, because AISI 8620 steel material is a good conductor, it spread the heat to the external environment until thermal balance was reached. Then the temperature became almost constant.

(d) PA 66 GFR 30-AISI 8620 couple gears showed no damage at $750 \mathrm{rpm}$, but, with the increase of rotation, heat accumulation was observed under the pitch circle. 


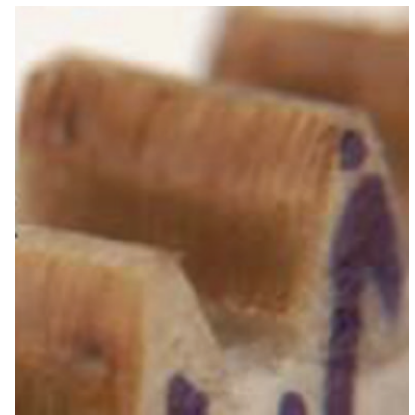

(a)

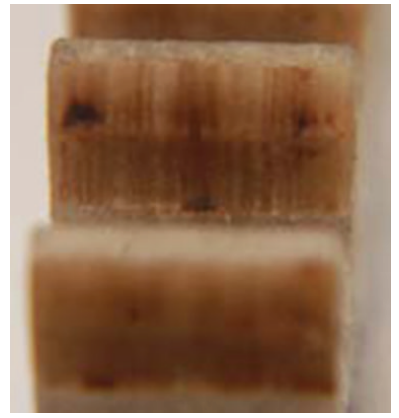

(b)

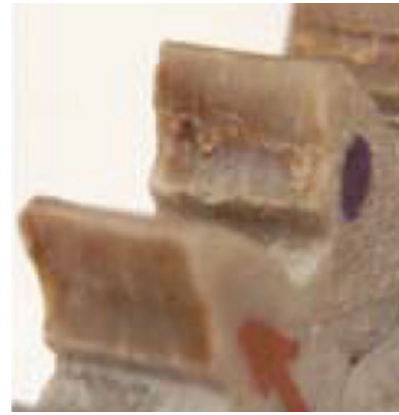

(c)

Figure 5: $56.75 \mathrm{~N} / \mathrm{mm}$ tooth load, PA 66 GFR 30-PA 66 GFR couple gear, and tooth damage: (a) $750 \mathrm{rpm}$, (b) $1000 \mathrm{rpm}$, and (c) $1500 \mathrm{rpm}$.

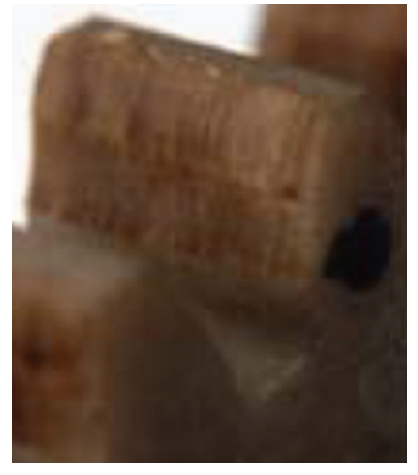

(a)

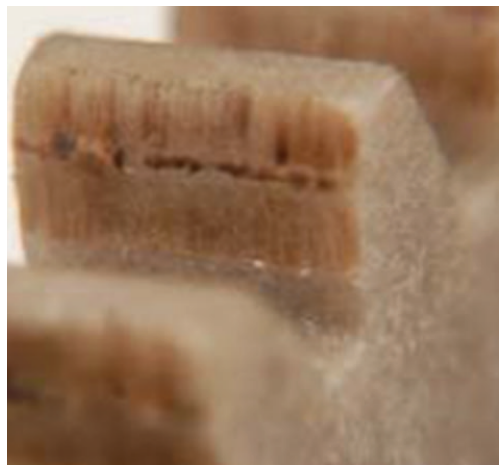

(b)

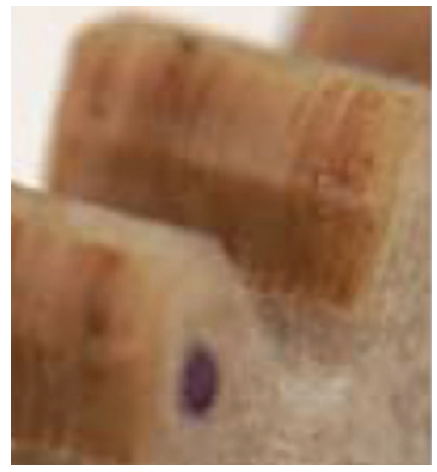

(c)

FigURE 6: $56.75 \mathrm{~N} / \mathrm{mm}$ tooth load, PA 66 GFR 30-AISI 8620 couple gear, and tooth damage: (a) $750 \mathrm{rpm}$, (b) $1000 \mathrm{rpm}$, and (c) $1500 \mathrm{rpm}$.

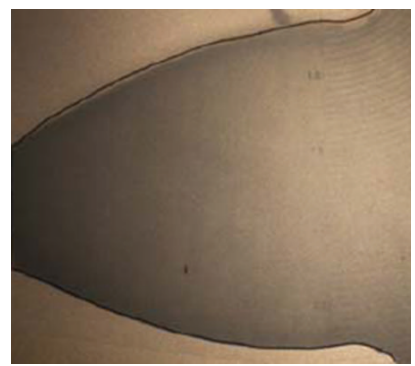

(a)

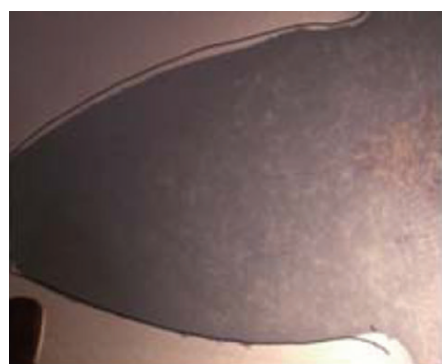

(b)

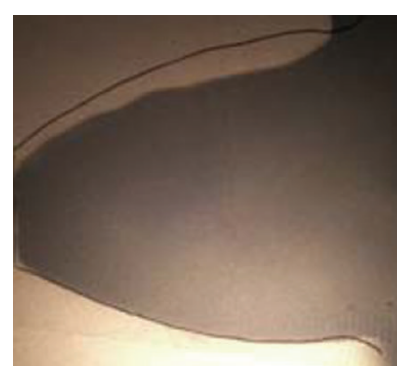

(c)

FIGURE 7: $56.75 \mathrm{~N} / \mathrm{mm}$ tooth load, PA 66 GFR 30-PA 66 GFR couple gear, and tooth damage: (a) $750 \mathrm{rpm}$, (b) $1000 \mathrm{rpm}$, and (c) $1500 \mathrm{rpm}$ abrasion on tooth profile.

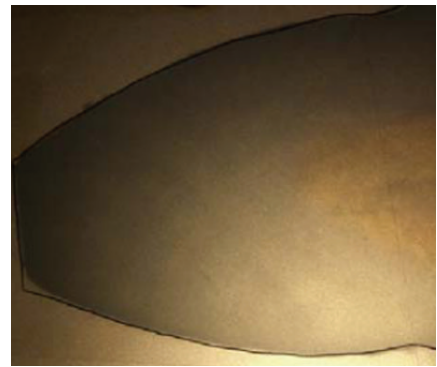

(a)

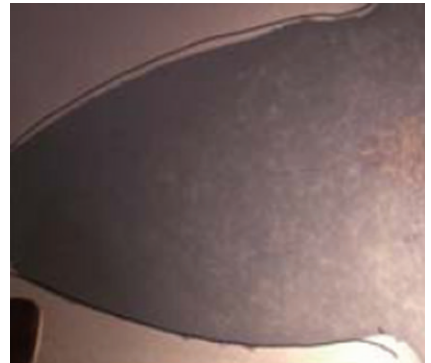

(b)

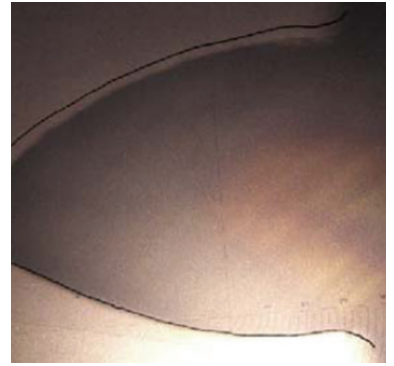

(c)

Figure 8: $56.75 \mathrm{~N} / \mathrm{mm}$ tooth load, PA 66 GFR 30-AISI 8620 couple gear, and tooth damage: (a) $750 \mathrm{rpm}$, (b) $1000 \mathrm{rpm}$, and (c) $1500 \mathrm{rpm}$ abrasion on tooth profile. 


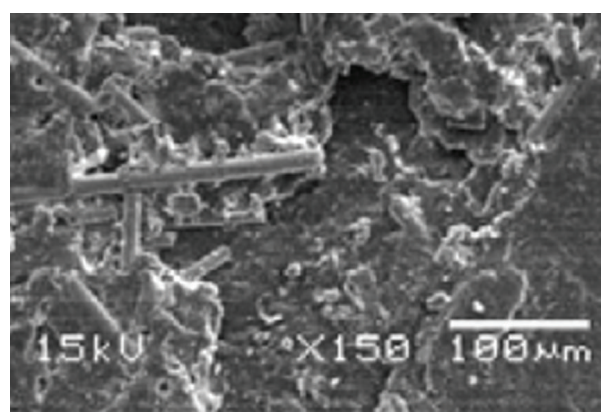

(a)

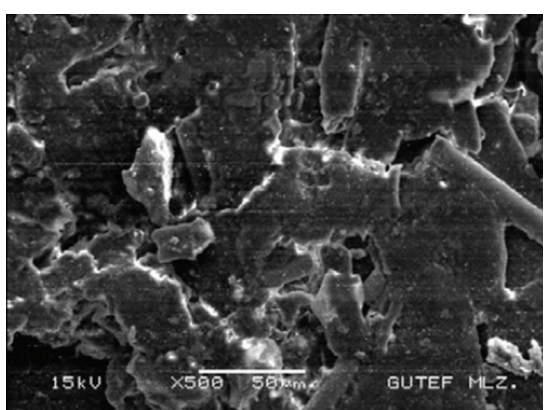

(b)

FIGURE 9: SEM image of gears at 56.75 N/mm tooth load: (a) $1000 \mathrm{rpm}$ PA 66 GFR 30-PA 66 GFR 30, (b) 1000 rpm PA 66 GFR $30-A I S I 8620$.

(e) During operation, AISI 8620 couple gears make their own profile on PA 66 GFR 30 gears and therefore they operate silently.

(f) To acquire ideal working conditions with plastic-type gears, tooth load and cycle period must be selected appropriately.

\section{Conflict of Interests}

The authors declare that there is no conflict of interests regarding the publication of this paper.

\section{References}

[1] B. İşel, Forming a surface fatigue test device for gears and studying the lube temperature effect [M.S. thesis], Afyon Kocatepe University Science Institute, 2007.

[2] H. İmrek and H. Düzcükoğlu, "Relation between wear and tooth width modification in spur gears," Wear, vol. 262, no. 3-4, pp. 390-394, 2007.

[3] K. Kızılaslan, B. İşel, and İ. Yavuz, "Damage types occur on gears," Machine Technologies Electronical Magazine, vol. 7, no. 1, pp. 119-129, 2010.

[4] H. Düzcükoglu, M. T. Demirci, R. Yakut, and Ş. Ekinci, “The effect of contact heat on plastic gear tooth surface to the tooth damage," in Proceedings of the 5th International Advanced Technologies Symposium (IATS '09), Karabük, Turkey, May 2009.

[5] M. Aksulu and M. Palabiyık, "The effect of opposing surface on abrasion of Poliamid 6," ITÜ̈ Dergisi/d Engineering, vol. 8, no. 2, pp. 63-71, 2009.

[6] R. Yakut, Experimenting with the load capacity and damage occurrence of thermoplastic gears [M.S. thesis], S.Ü. FBE, 2008.

[7] K. Mao, W. Li, C. J. Hooke, and D. Walton, "Friction and wear behaviour of acetal and nylon gears," Wear, vol. 267, no. 1-4, pp. 639-645, 2009.

[8] M. Yüksel, "Material information," in TMMOB-Mechanical Engineers Chamber, vol. 1, pp. 304-338, Denizli Branch Publications, Denizli, Turkey, 1998.

[9] N. A. Wright and S. N. Kukureka, "Wear testing and measurement techniques for polymer composite gears," Wear, vol. 251, no. 1-12, pp. 1567-1578, 2001.

[10] T. Eritenel, S. M. Vijayakar, D. R. Houser, and J. M. Casella, "Effect of tooth deflection and corner contact on backside separation (backlash) of gear pairs," in Proceedings of the ASME Design Engineering Technical Conferences and Computers and Information in Engineering Conference, pp. 103-110, Chicago, Ill, USA, September 2003.

[11] S. Senthilvelan and R. Gnanamoorthy, "Effect of rotational speed on the performance of unreinforced and glass fiber reinforced Nylon 6 spur gears," Materials and Design, vol. 28, no. 3, pp. 765-772, 2007.

[12] H. Düzcükoglu and H. Imrek, "A new method for preventing premature pitting formation on spur gears," Engineering Fracture Mechanics, vol. 75, no. 15, pp. 4431-4438, 2008.

[13] H. Düzcükoglu, "PA 66 spur gear durability improvement with tooth width modification," Materials and Design, vol. 30, no. 4, pp. 1060-1067, 2009.

[14] H. Düzcükoglu, R. Yakut, and M. T. Demirci, "The load capacity of PC/ABS spur gears and investigation of gear damage," Archives of Materials Science and Engineering, vol. 40, no. 1, pp. 41-46, 2009.

[15] A. R. Breeds, S. N. Kukureka, K. Mao, D. Walton, and C. J. Hooke, "Wear behaviour of acetal gear pairs," Wear, vol. 166, no. 1, pp. 85-91, 1993.

[16] N. Tsukamoto, H. Maruyama, and H. Mimura, "Effect of reducing friction of polyacetal in gears," Transactions of the JSME C, vol. 57, pp. 230-235, 1985.

[17] H. Can, Prestressed plastic gear design [M.S. thesis], Gazi University Science Institute, Ankara, Turkey, 2004. 

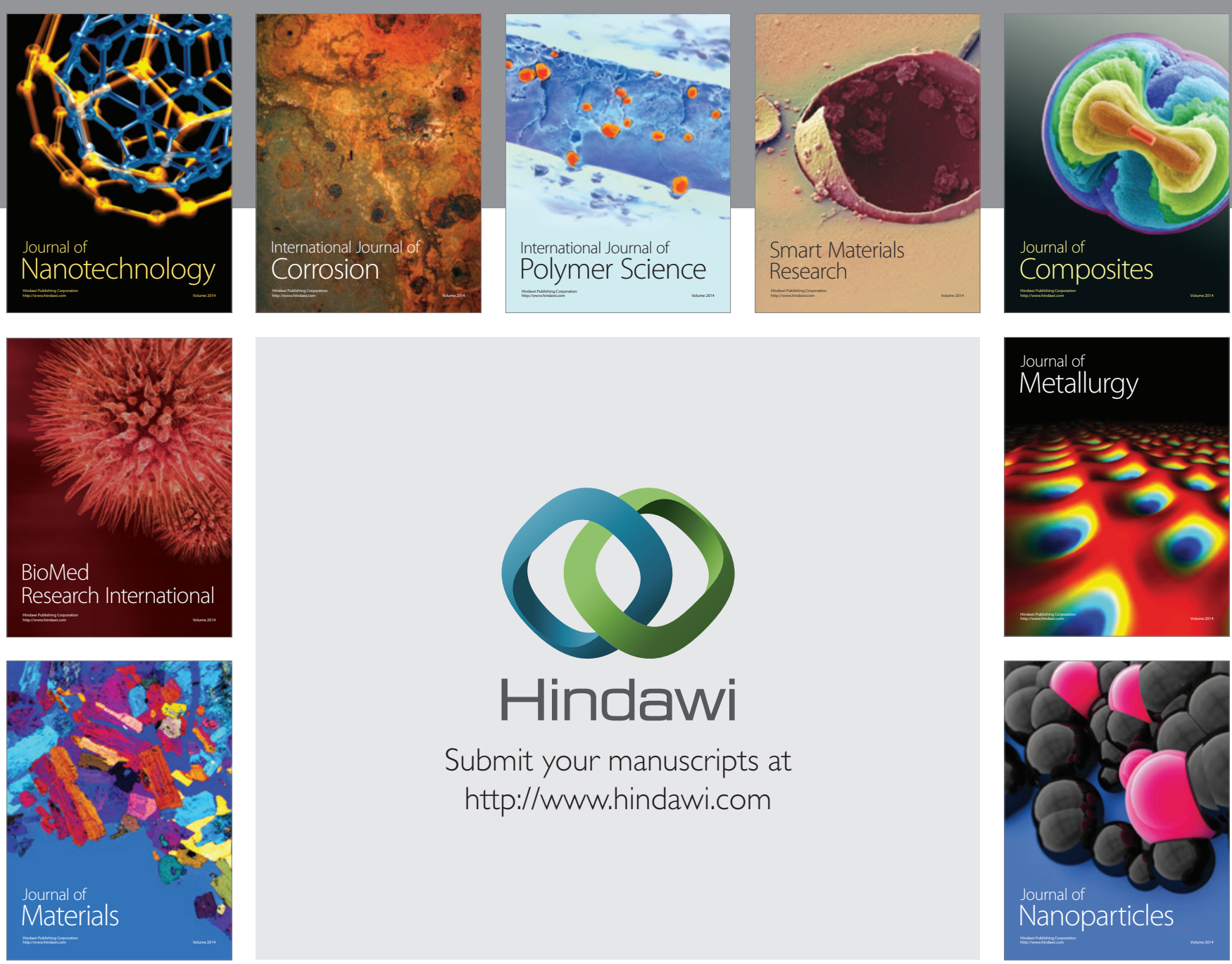

Submit your manuscripts at http://www.hindawi.com
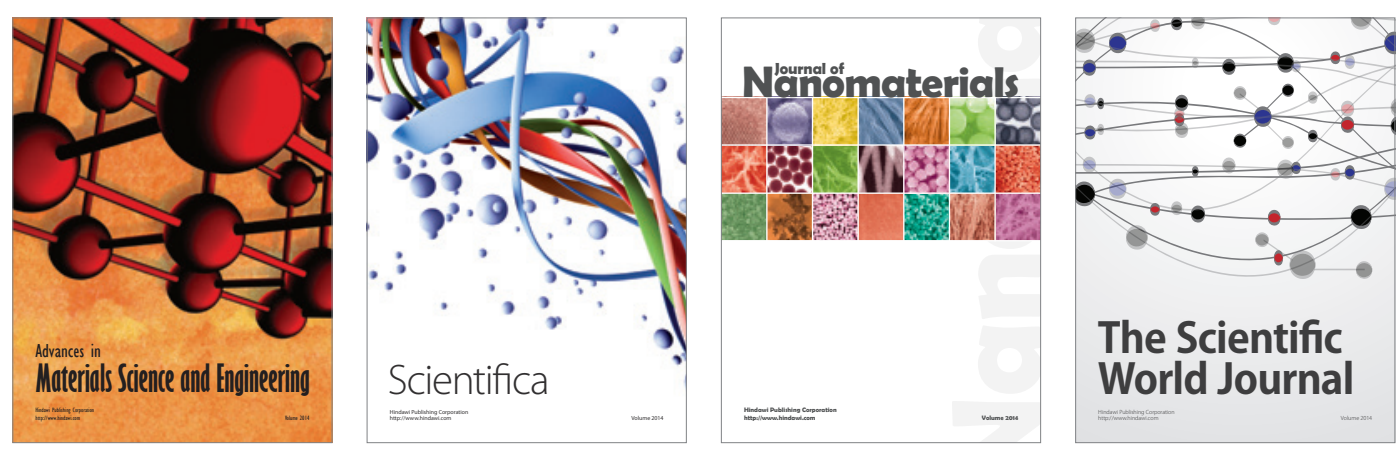

\section{The Scientific World Journal}
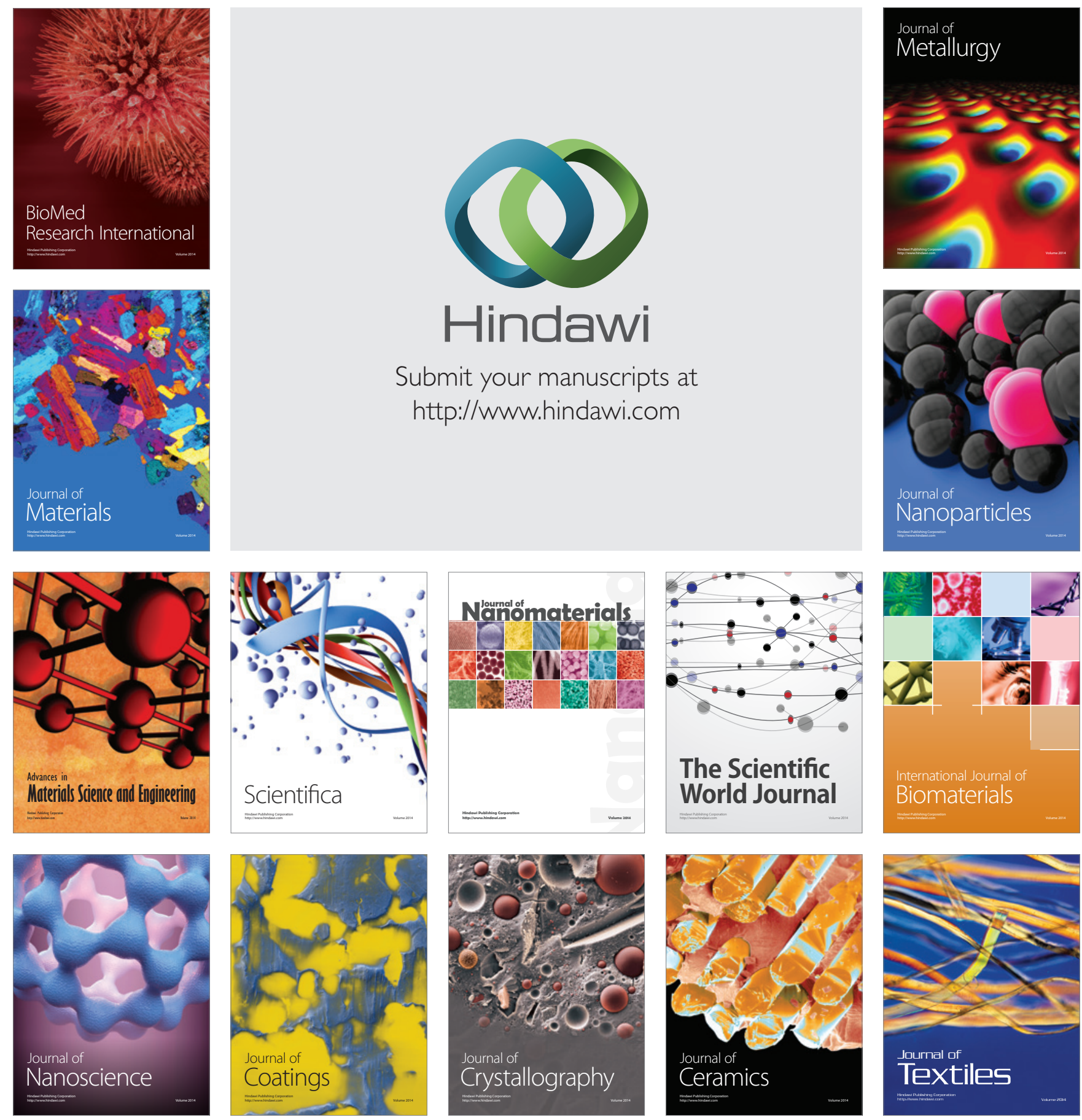